\title{
No evidence for shedding of circulating tumor cells to the peripheral venous blood as a result of mammographic breast compression
}

\author{
Daniel Förnvik · Ingvar Andersson • Magnus Dustler · Roy Ehrnström • \\ Lisa Rydén · Anders Tingberg $\cdot$ Sophia Zackrisson $\cdot$ Kristina Aaltonen
}

Received: 22 July 2013/ Accepted: 17 August 2013/Published online: 29 August 2013

(c) The Author(s) 2013. This article is published with open access at Springerlink.com

\begin{abstract}
This pilot study aimed to investigate whether mammographic compression procedures might cause shedding of tumor cells into the circulatory system as reflected by circulating tumor cell (CTC) count in peripheral venous blood samples. From March to October 2012, 24 subjects with strong suspicion of breast malignancy were included in the study. Peripheral blood samples were acquired before and after mammography. Enumeration of CTCs in the blood samples was performed using the CellSearch $^{\circledR}$ system. The pressure distribution over the tumor-containing breast was measured using thin pressure sensors. The median age was 66.5 years (range, 51-87 years). In 22 of the 24 subjects, breast cancer was subsequently confirmed. The difference between the average mean tumor pressure $6.8 \pm 5.3 \mathrm{kPa}$ (range,
\end{abstract}

D. Förnvik $(\bowtie) \cdot$ M. Dustler · A. Tingberg

Medical Radiation Physics, Department of Clinical Sciences,

Lund University, Skåne University Hospital Malmö,

20502 Malmö, Sweden

e-mail: daniel.fornvik@med.lu.se

I. Andersson · S. Zackrisson

Diagnostic Radiology, Department of Clinical Sciences, Lund University, Skåne University Hospital Malmö, 20502 Malmö, Sweden

\section{R. Ehrnström}

University and Regional Laboratories Region Skåne, Department of Pathology, Skåne University Hospital Malmö, 20502 Malmö, Sweden

\section{Rydén}

Surgery, Department of Clinical Sciences, Lund University, Skåne University Hospital Lund, 22221 Lund, Sweden

\section{K. Aaltonen}

Oncology, Department of Clinical Sciences, Lund University, Skåne University Hospital Lund, 22221 Lund, Sweden
$1.0-22.5 \mathrm{kPa}$ ) and the average mean breast pressure $3.4 \pm 1.6 \mathrm{kPa}$ (range, $1.5-7.1 \mathrm{kPa}$ ) was statistically significant $(p<0.001)$, confirming that there was increased pressure over the tumor. The median pathological tumor size was $19 \mathrm{~mm}$ (range, 9-30 mm). Four subjects $(17 \%)$ were CTC positive before compression and two of these $(8 \%)$ were also CTC positive after compression. A total of seven CTCs were isolated with a mean size of $8 \times 6 \mu \mathrm{m}^{2}$ (range of the longest diameter, 5-12 $\mu \mathrm{m}$ ). The study supports the view that mammography is a safe procedure from the point of view of tumor cell shedding to the peripheral blood.

Keywords Circulating tumor cells $\cdot$ Breast compression - Breast cancer $\cdot$ Mammography

\section{Introduction}

Mammography is the gold standard imaging method of the breast. Compression of the breast during mammography is performed to improve image quality by increasing breast tissue separation and reducing scattered radiation, and to minimize the radiation dose to the breast, which is one of the most radiosensitive tissues of the female body. For these reasons, the breast is compressed as much as reasonably possible to a level just below the patient's pain threshold or up to the maximum setting of the machine (generally $200 \mathrm{~N}$ ). It has long been discussed whether this applied pressure may damage a tumor, resulting in shedding of malignant cells into the circulatory system and whether this in turn will affect the prognosis [1-3]. Several publications have stressed the need for caution in cancer surgery, emphasizing the importance of minimizing tumor manipulation to avoid dissemination of malignant cells [4-8]. Older studies have found that 
moderate pressure applied to tumors in small animals caused the number of cancer cells per ml blood to rise drastically or the incidence of distant metastases to increase compared to controls [9-12]. This is a relevant concern for mammography since the most important and detrimental step in the progression of breast cancer is the occurrence of metastatic disease through dissemination of cancer cells to other parts of the body.

Many critical steps of the metastatic cascade are unclear, including how malignant cells (possibly due to acquired features) can give rise to overt metastasis in secondary organs. One of the first steps in the metastatic process is the spread of tumor cells into the blood circulation. These circulating tumor cells (CTCs) have left the primary tumor and studies have confirmed that the CTC count per unit of blood is an independent prognostic marker for progressionfree survival and overall survival in several types of cancer [13-15]. Also, the CTC count in peripheral blood of metastatic cancer patients during therapy directly reflects the patient's response to therapy $[16,17]$. The prognostic role of CTC in primary (non-metastatic) cancer has not been widely investigated [18], but a few studies have shown that the presence of CTCs can predict poor prognosis also in patients with primary breast cancer $[15,19,20]$. Furthermore, a prospective study by Lucci et al. [21] has shown that the presence of one or more CTCs predicted both early recurrence and decreased overall survival in 302 nonmetastatic breast cancer patients independent of prognostic factors such as tumor size or grade. Franken et al. [22] included 404 stage I-III patients and showed that the presence of CTCs $(\geq 1 / 30 \mathrm{ml})$ was associated with an increased risk for breast cancer-related death. Thus, the presence of CTCs seems to be an important prognostic factor also in women with primary breast cancer.

We hypothesized that damage to a tumor, caused by the pressure arising from compression of the breast, might release tumor cells into the blood stream. The aim of this pilot study was to investigate whether mammographic compression procedures might cause shedding of tumor cells as reflected by a relative increase in CTC count in peripheral blood samples. To examine a possible correlation between the magnitude of the pressure and the CTC count, we measured the applied pressure to the tumor and the rest of the breast.

\section{Materials and methods}

Study population

Subjects were recruited among patients referred for clinical mammography as well as from the screening program. Patients from the clinical practice (below referred to as symptomatic women) were selected if information on clinical findings in the referral notes indicated a strong suspicion of malignancy, e.g., firm mass with dimpling of the skin. Subjects from the screening program were selected on the basis of the screening mammogram showing a strong suspicion of malignancy (BIRADS 4 or 5) requiring recall for further investigation. A total of 24 subjects were included from March to October 2012. Eleven $(46 \%)$ of the subjects were symptomatic and 13 $(54 \%)$ were asymptomatic. The asymptomatic subjects had their screening mammogram a median of 14 days (range, 8-38 days) before the first blood sample was drawn. The workflow is illustrated in Fig. 1.

The Regional Ethical Review Board at Lund University (Dnr 314/2011) approved the study. Written informed consent was obtained from all included patients and all examinations were voluntary.

Blood sampling and image acquisition

All blood samples were drawn from either a cubital vein $(97 \%)$ or a vein on the dorsal aspect of the hand $(3 \%)$. The first blood sample was drawn immediately before the mammography examination, but in the symptomatic patients, after an ultrasound examination using minimal pressure on the probe. The rationale of the ultrasound was to confirm the presence of a suspicious lesion (Fig. 1). All subjects then underwent three projection views of the breast of interest: craniocaudal (CC), mediolateral oblique (MLO) ,and lateromedial (LM) using the Siemens

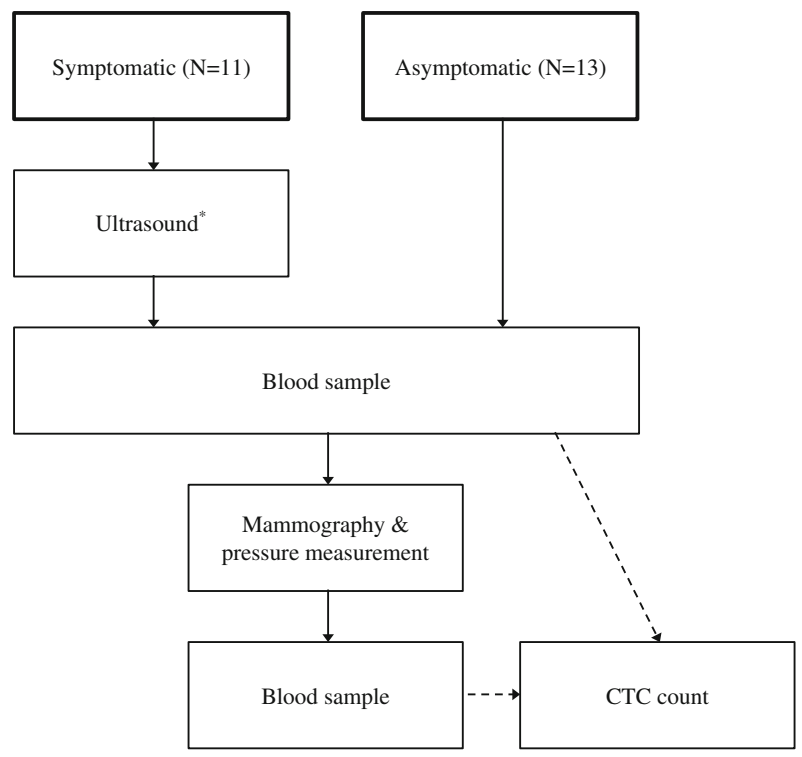

"As a first step in the in vestigation the cancer suspicion was verified by an ultrasound examination of the tumor area applying as little pressure as possible.

Fig. 1 Flow chart of the study 
MAMMOMAT Inspiration system (Siemens AG, Erlangen, Germany). In 22/24 (92\%) of the subjects, the pressure distribution was recorded in the CC projection image; in the remaining two of the subjects ( $8 \%$ ), it was recorded in the MLO projection image. After completed mammography examination, the second blood sample was drawn. This occurred on average $5.1 \mathrm{~min}$ (range 2-14 min) after the pressure distribution was recorded. All patients underwent needle biopsy after the above procedures.

\section{Pressure measurement system}

The pressure distribution over the compressed breast was measured using two thin, flexible I-Scan (TekScan Inc., South Boston, MA, USA) force-sensing resistor (FSR) pressure sensors (model 9801). Each sensor is $0.18 \mathrm{~mm}$ thick and has an active area of $76 \times 203 \mathrm{~mm}^{2}$, divided into $6 \times 16$ sensor elements. The sensors were calibrated and verified before each subject measurement and the sensitivity was set according to previous experience [23]. The pressure resolution at this setting is roughly $0.14 \mathrm{kPa}$ with a saturation limit between 30 and $35 \mathrm{kPa}$. The performance of the I-Scan system has been verified previously and evaluated under conditions similar to those used in this study [23-25].

\section{Pressure distribution acquisition}

Two sensors were fastened adjacent to one another underneath the compression paddle (model 1014011, dimensions: $28 \times 20 \times 0.16 \mathrm{~cm}^{3}$ ) (Fig. 2) for one of the projection images (see above) and then removed before the remaining images were acquired because the sensors are radiopaque (Fig. 3). The pressure image was obtained using our routine technique in terms of positioning and compression force. The output from the sensors was stored and compression force and thickness were recorded as indicated by the mammographic device. Pressure data and the corresponding projection images were used to create composite images (Fig. 3). The pressure column closest to the chest wall (the first 16 sensor elements) was excluded from the analysis as this column is usually outside the mammogram and characterized by high pressure values due to the inclusion of superficial parts of the chest wall [23]. A medical physicist (DF) together with an experienced radiologist (IA) decided in consensus which pressure elements covered the tumor areas.

Enumeration and definition of circulating tumor cells

Enumeration of CTCs in the blood circulation was performed with the food and drug administration (FDA)-approved CellSearch ${ }^{\circledR}$ method (Veridex, Raritan, NJ, USA). Peripheral

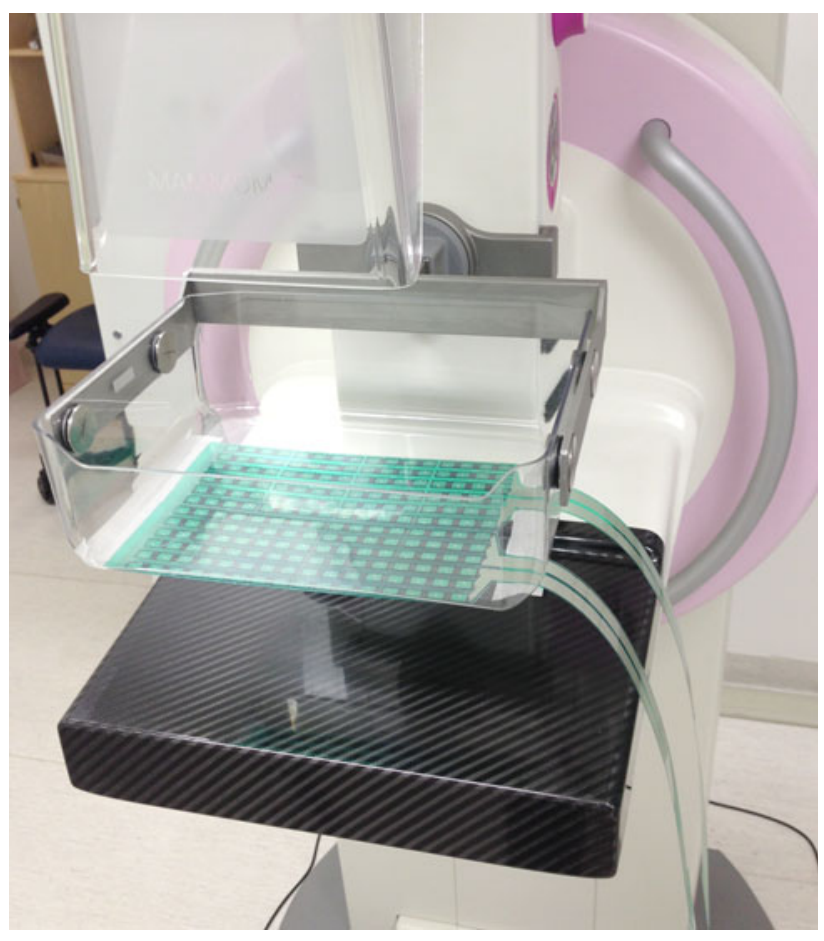

Fig. 2 Two FSR pressure sensors fastened underneath the compression paddle

blood was drawn into CellSave preservative tubes $(7.5 \mathrm{ml})$ (Veridex). Two samples were drawn before compression and two samples after compression to increase the likelihood of detecting possible CTCs. The first 3-5 $\mathrm{ml}$ of each blood sampling was discarded before the sample for analysis was collected in order to avoid contamination of skin epithelial cells. Samples were maintained at room temperature and processed within $96 \mathrm{~h}$ after blood collection. The methodology and the precision, accuracy, and reproducibility of CTC measurements using the CellSearch ${ }^{\circledR}$ system have been described previously [26, 27]. Briefly, antibodies conjugated to ferro-fluid particles were used to magnetically isolate cells expressing the epithelial cell adhesion molecule (EpCAM). Unbound cells were removed and the enriched sample was fluorescently stained for nucleic acids (DAPI), cytokeratins (CK 8, 18, and 19), and CD45. Cells with a size of at least $4 \mu \mathrm{m}$ presenting the phenotype DAPI+/CK $+/ \mathrm{CD} 45-$ were classified as CTCs. All CTC evaluations were performed at the Department of Oncology (Clinical Sciences, Lund University, Sweden), by two accredited and independent scorers. In this study, the presence of one or more CTCs in any of the two pairs of samples (before and after) was considered CTC positive $[15,18,22,28,29]$.

Staging and pathology review

Information on tumor histology, staging, and prognostic factors was retrieved from pathology reports (Skåne 


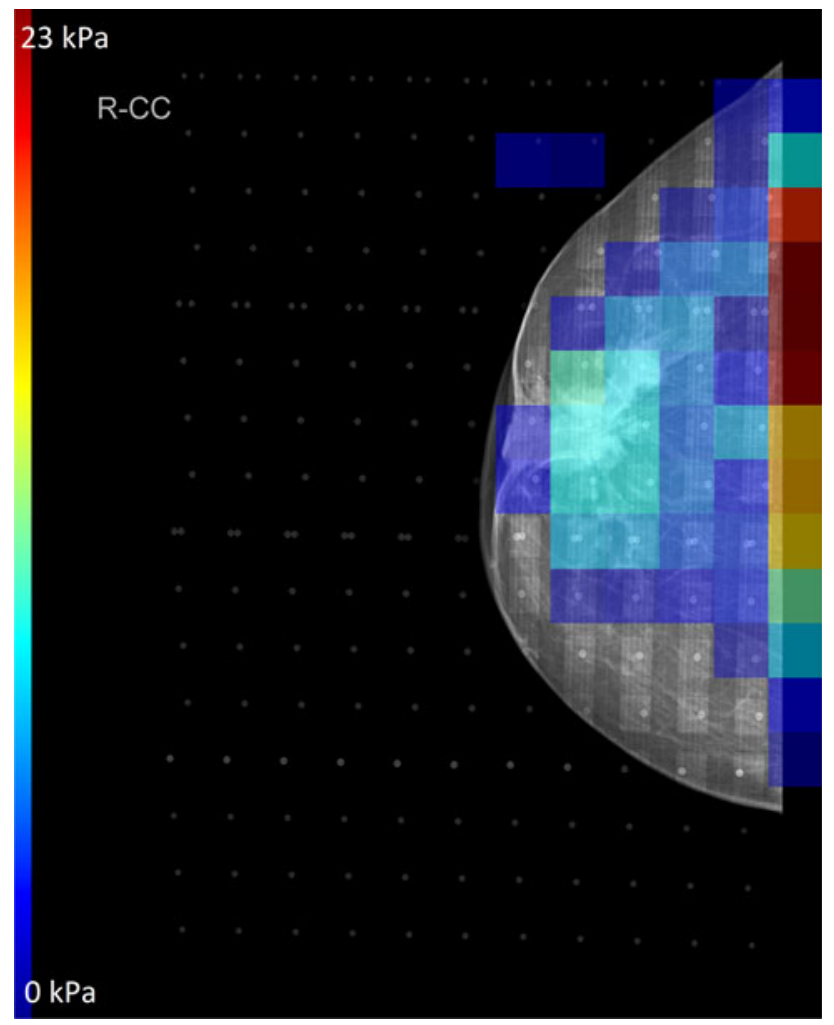

Fig. 3 A 65-year-old woman (subject 4) with a 30-mm, grade 2, invasive ductal carcinoma. Note the spiculated tumor with retraction of the nipple-areolar complex. Pressure is shown on a scale from dark blue (lowest) to dark red (highest). The maximum tumor pressure was $10 \mathrm{kPa}$ (mean tumor pressure, $8.9 \mathrm{kPa}$ ). This patient had $1 \mathrm{CTC}$ before compression and $1 \mathrm{CTC}$ after compression

University Hospital, Malmö, Sweden). All patients underwent primary surgery according to regional guidelines including mastectomy or breast-conserving surgery as well as sentinel node biopsy. In patients with metastatic sentinel node, axillary clearance was performed. The tumor size was given as the largest measured histologic value of the $x$ ,$y$-, and $z$-axis of the tumor. Axillary node involvement was classified as positive in the presence of micro- and macrometastases, as negative in the presence of only isolated tumor cells or no node involvement, or not applicable (N/A). All tumors were classified as well as graded according to the Nottingham (Elston/Ellis) grading system. Multifocal tumors were characterized by multiple foci of tumor cells found in the same breast quadrant with intervening ordinary stroma. Vascular invasion was determined by immunohistochemistry (IHC) of CD34 and CD31 (BD Pharmingen) to detect blood vessels and podoplanin/D2-40 (Signet antibodies) to detect lymphatic vessels. Estrogen receptor (ER)- and progesterone receptor (PR) positivity was evaluated by IHC with monoclonal antibodies (Ventana/Roche) with a cutoff for positivity set to $>10 \%$. Human epidermal growth factor receptor 2 (HER2) status was determined according to international standards [30]. Ki67 expression was measured with the antibody M1B1 (DAKO) and the cutoff for positivity was set to $>20 \%$ positively stained tumor cells.

\section{Statistical analysis}

The number of patients with positive CTCs was too small to perform any correlation tests or multivariate analysis. A paired $t$ test was used to determine if there was a statistically significant difference between the pressure exerted over the tumor and the surrounding breast parenchyma. A MannWhitney test was used to assess differences between symptomatic and asymptomatic subjects with regard to tumor characteristics. All analyses were performed using the SPSS software (version 20; SPSS Inc., Chicago, IL, USA) and $p$ values $<0.05$ were considered statistically significant.

\section{Results}

\section{Pathology findings}

The median age of the subjects was 66.5 years (range, 51-87 years). Of the 24 subjects, $15(63 \%)$ had invasive ductal carcinomas (IDC), three (13\%) had invasive lobular carcinomas (ILC), four (17\%) had other types of carcinoma, one (4\%) had non-Hodgkin's lymphoma, and one (4\%) had a benign cyst (Table 1 ). The median pathological tumor size was $19 \mathrm{~mm}$ (range, $9-30 \mathrm{~mm}$ ). Twelve $(55 \%)$ of the malignant breast tumors were histologic grade 1 or 2 and eight (36\%) were grade 3. Four (18\%) were HER2 positive, six $(27 \%)$ were ER negative, and $11(50 \%)$ were PR negative. One (5\%) of the subjects showed vascular invasion and $13(59 \%)$ had Ki67 > $20 \%$. There were no apparent differences between tumor characteristics in symptomatic and asymptomatic women $(p>0.05)$, but a trend for larger tumor sizes was seen in the symptomatic group $(p=0.10)$.

\section{Pressure}

The average applied compression force over the breast with pressure sensors attached was $105.1 \pm 17.6 \mathrm{~N}$ (range 54-132 N). The average breast thickness in the same projection was $45.1 \pm 12.2 \mathrm{~mm}$ (range 19-73 mm).

The average maximum tumor pressure was $10.1 \pm 8.4 \mathrm{kPa}$ (range 1.0-36.1 kPa) and the average mean tumor pressure was $6.8 \pm 5.3 \mathrm{kPa}$ (range 1.0-22.5 kPa). The difference between the average mean tumor pressure and the average mean breast pressure $3.4 \pm 1.6 \mathrm{kPa}$ (range $1.5-7.1 \mathrm{kPa}$ ) was statistically significant $(p<0.001)$. Thus, the pressure was, on average, higher over the tumor compared to the rest of the breast and confirms that there is substantial pressure over the tumor. An 
Table 1 Tumor characteristics and descriptive data of the 24 study subjects

\begin{tabular}{|c|c|c|c|c|c|c|c|c|c|c|c|c|c|c|}
\hline Subject & $\begin{array}{l}\text { Age } \\
\text { (years) }\end{array}$ & $\begin{array}{l}\text { CTC } \\
\text { before }\end{array}$ & $\begin{array}{l}\text { CTC } \\
\text { after }\end{array}$ & $\begin{array}{l}\text { Maximum } \\
\text { tumor pressure } \\
(\mathrm{kPa})\end{array}$ & $\begin{array}{l}\text { Tumor } \\
\text { size } \\
(\mathrm{mm})\end{array}$ & $\begin{array}{l}\text { Nodal } \\
\text { status }\end{array}$ & Histology & $\begin{array}{l}\text { Histologic } \\
\text { grade }\end{array}$ & Multifocal & $\begin{array}{l}\text { Vascular } \\
\text { invasion }\end{array}$ & ER & PR & HER2 & $\begin{array}{l}\mathrm{Ki}-67 \\
(\%)\end{array}$ \\
\hline 1 (a) & 66 & 0 & 0 & 13 & 21 & - & IDC & 3 & + & - & + & + & - & 50 \\
\hline 2 (a) & 70 & 0 & 0 & 7 & 13 & - & IDC & 3 & - & - & - & - & - & 70 \\
\hline $3(\mathrm{~s})$ & 85 & 0 & 0 & 9 & NA & NA & $\begin{array}{l}\text { Non-Hodgkin's } \\
\text { lymphoma }\end{array}$ & NA & NA & NA & NA & $\mathrm{NA}$ & NA & NA \\
\hline 4 (a) & 65 & 1 & 1 & 10 & 30 & - & IDC & 2 & - & - & + & + & - & 15 \\
\hline 5 (a) & 51 & 0 & 0 & 11 & 19 & - & $\begin{array}{l}\text { Medullary } \\
\text { carcinoma }\end{array}$ & 3 & - & - & - & - & - & 80 \\
\hline 6 (a) & 51 & 0 & 0 & 10 & 12 & - & IDC & 2 & - & - & + & + & - & 25 \\
\hline $7(\mathrm{~s})$ & 83 & 0 & 0 & 4 & 17 & - & $\begin{array}{l}\text { Intracystic } \\
\text { papillary } \\
\text { carcinoma }\end{array}$ & 2 & - & NA & + & + & - & NA \\
\hline 8 (a) & 58 & 1 & 0 & 7 & 13 & - & IDC & 1 & - & - & + & - & - & 14 \\
\hline 9 (a) & 61 & 0 & 0 & 1 & 11 & - & IDC & 3 & - & - & + & + & - & 30 \\
\hline $10(\mathrm{~s})$ & 85 & 0 & 0 & 14 & 22 & + & IDC & 3 & - & - & + & - & + & 75 \\
\hline 11 (a) & 64 & 0 & 0 & 4 & 9 & - & $\begin{array}{l}\text { Metaplastic } \\
\text { carcinoma }\end{array}$ & 3 & - & - & - & - & + & 30 \\
\hline $12(\mathrm{~s})$ & 87 & 0 & 0 & 12 & 19 & - & IDC & 2 & + & - & + & + & - & 17 \\
\hline $13(\mathrm{~s})$ & 78 & 0 & 0 & 11 & 25 & - & IDC & 3 & - & - & - & - & + & 35 \\
\hline $14(\mathrm{~s})$ & 77 & 1 & 0 & 3 & NA & NA & Benign cyst & NA & NA & NA & NA & NA & NA & NA \\
\hline 15 (a) & 63 & 0 & 0 & 20 & 20 & + & IDC & 1 & - & + & + & + & - & 15 \\
\hline $16(\mathrm{~s})$ & 83 & 0 & 0 & 2 & 19 & - & IDC & 2 & - & - & + & + & - & 21 \\
\hline $17(\mathrm{~s})$ & 67 & 0 & 0 & 6 & 22 & + & ILC & 2 & - & - & + & + & - & 5 \\
\hline $18(\mathrm{~s})$ & 58 & 0 & 0 & 36 & 12 & + & IDC & 1 & - & - & + & - & - & 10 \\
\hline 19 (a) & 63 & 0 & 0 & 24 & 15 & - & IDC & 2 & - & - & + & - & - & 45 \\
\hline $20(\mathrm{~s})$ & 81 & 2 & 1 & 4 & 25 & + & ILC & 3 & - & - & + & - & - & 24 \\
\hline 21 (a) & 70 & 0 & 0 & 17 & 10 & + & ILC & 1 & + & - & + & + & - & 13 \\
\hline $22(\mathrm{~s})$ & 63 & 0 & 0 & 3 & 25 & - & IDC & 3 & - & - & - & - & - & 80 \\
\hline 23 (a) & 72 & 0 & 0 & 6 & 17 & - & IDC & 3 & - & - & + & + & - & 25 \\
\hline 24 (a) & 66 & 0 & 0 & NA & 30 & + & $\begin{array}{l}\text { Apokrine } \\
\text { carcinoma }\end{array}$ & 2 & - & - & - & - & - & 21 \\
\hline
\end{tabular}

$a$ Asymptomatic, $s$ symptomatic, $N A$ not applicable, $E R$ estrogen receptor, $P R$ progesterone receptor, $H E R 2$ human epidermal growth factor receptor $2, I D C$ invasive ductal carcinoma, ILC invasive lobular carcinoma

example of a composite image with pressure data displayed as a color overlay is shown in Fig. 3.

\section{CTC evaluation}

Four subjects $(17 \%)$ were CTC positive before compression and two of these ( $8 \%$ ) were also CTC positive after compression. There was no significant difference between the number of symptomatic $(50 \%)$ and asymptomatic $(50 \%)$ subjects with respect to CTC positivity $(p>0.05)$. A total of seven CTCs were isolated in the samples of all CTC-positive subjects with a mean size of $8 \times 6 \mu \mathrm{m}$ (range of the longest diameter, 5-12 $\mu \mathrm{m}$ ) (Fig. 4). No relationships could be found between the presence of CTC and applied pressure or any pathological factors. An interesting observation, however, is that the two patients with CTC-positive results before and after compression had a tumor size above the median $(25$ and $30 \mathrm{~mm}$, respectively) (Table 1).

\section{Discussion}

This study aimed at investigating whether malignant tumor cells are shed and detectable in peripheral venous blood during mammographic compression. To the authors' knowledge, this is the first study investigating this issue. In this pilot study, we found no evidence of tumor cell shedding to the peripheral blood, as opposed to a substantial number of animal studies [9-12], surgery shedding studies [4-8], and opinions expressed in letters of concern [1-3] regarding tumor cell shedding following manipulation of the primary tumor. The presence of $\geq 1$ CTC in $17 \%$ of our subjects is close to the span of other studies (using different volumes of blood) of primary breast cancer patients (19-31\%) [15, 18, 20, 22, 31]. We could not find any relationship between the presence of CTCs and tumor characteristics (Table 1), which is consistent with other studies that have also found a lack of correlation between CTCs and histopathological factors [18, 29, 32]. We 
Fig. 4 Example of CTCs from the subjects with malignant disease in the study. The analysis was performed with the CellSearch ${ }^{\circledR}$ system (Veridex) and cells positive for CK-PE/ DAPI and negative for CD45APC/control (right column) were considered CTCs

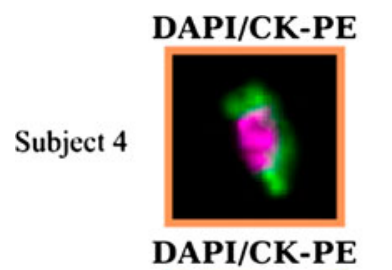

Subject 8

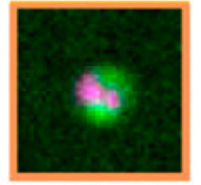

DAPI/CK-PE

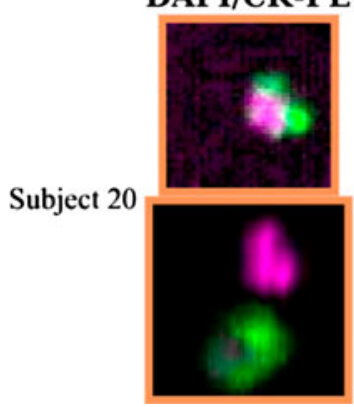

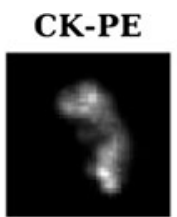

CK-PE

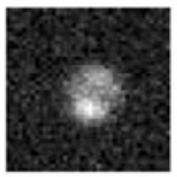

CK-PE
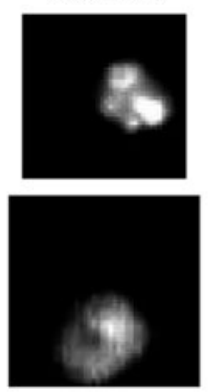

DAPI

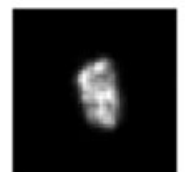

DAPI

CD45-APC

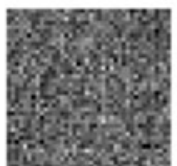

CD45-APC

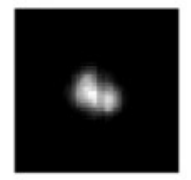

DAPI
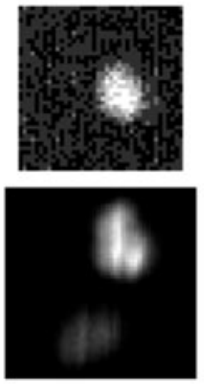

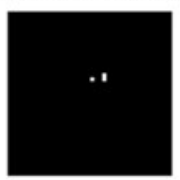

CD45-APC
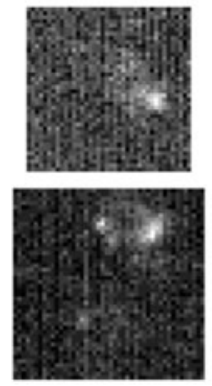
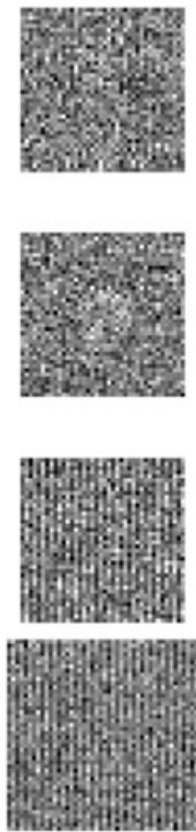

assumed that cancers with a medullary growth pattern including some grade 3 invasive ductal cancers which are often also well vascularized would be more prone to microruptures and shedding than cancers with productive fibrosis like many grade 1 and 2 ductal and lobular cancers. Our material might be too small to exclude such a possibility; however, our study indicates a low probability of a major shedding of CTCs to the peripheral venous blood as a result of mammographic compression.

One $(4 \%)$ of our CTC-positive subjects had a benign cyst. The reported percentages of patients with benign disease that are CTC positive are between $8 \%$ [26] and $15 \%$ [22]. Whether the presence of CTCs in patients with benign disease has any predictive value is currently unclear. It is possible that these cells are either nonmalignant epithelial cells that have been stimulated to migration by inflammatory cytokines or actual malignant CTCs released from a pre-malignant lesion as discussed in benign colon disease [33].

We found that the pressure over the tumor was higher than over the rest of the breast, which is attributed to the difference in tissue elasticity between abnormal and normal tissue structures. The pressure over the tumor from manipulating the breast during positioning and subsequent compression is in general quite low. Clinical exams/palpation and spot compression/magnification views would result in pressures to the tumor exceeding those applied in the current study [34]. It is plausible that the pressure applied in the aforementioned experimental studies of small animals exceeded the pressure applied with mammography. However, it is also clear that a cyst may occasionally rupture as a result of mammographic compression showing that the pressure is not insignificant [35].

A few concerns regarding the probability to find CTCs in the present study should be addressed. First, CTC enumeration follows a Poisson distribution and is limited by the sampling error inherent to rare event detection and the fact that only $\sim 0.15 \%(7.5 \mathrm{ml})$ of the total blood volume (5 1) is sampled in one CellSave preservative tube [26]. In this study, two samples were collected before and after compression (30 $\mathrm{ml}$ in total) for increased sensitivity. Second, despite its status as an FDA-approved method, one limitation of the CellSearch ${ }^{\circledR}$ system is that only CTCs expressing the epithelial marker EpCAM will be detected. EpCAM is likely to be (partly) downregulated during epithelial mesenchymal transition (EMT), which is the process when tumor cells leave the primary tumor to enter the blood stream [36]. An EpCAM-based method could thus lack the possibility to identify the most stem-like and aggressive cancer cells in the blood circulation. Also, cells in the "normal-like" subgroup of breast cancer sometimes lack EpCAM expression [37], causing these cells to avoid detection in many enumeration methods used today. Third, there exist no reliable data regarding the CTC half-life in human subjects. Meng et al. [38] estimate the half-life to be 1-2.4 h. The depletion kinetics of circulating prostate cancer cells were examined by Li et al. [39] and they found that $>70 \%$ of high-metastatic PC-3 cells and $<30 \%$ of low-metastatic LNCaP cells were depleted from the circulation after $1 \mathrm{~h}$ following tail vein injection of BALB/c nude mice. On the other hand, Romsdahl et al. [10] noticed a very fast depletion of CTCs with 93.6-99.6\% percent 
reduction $4 \mathrm{~min}$ after tumor manipulation. We collected our blood samples as fast as possible, on average $5.1 \mathrm{~min}$ after breast compression, limiting the possible half-life affect. But, there is a risk that we missed the cell seeding by collecting the samples either within a too short or too long time frame. In general, the limited knowledge of the biology of CTCs and the process of metastasis is a limiting factor in detecting the total number of CTCs present in cancer patients.

One can speculate about how a bolus of tumor cells to the blood would affect the patient prognosis. It is known that a decrease in the number of CTCs in metastatic breast cancer patients from unfavorable $(\geq 5 \mathrm{CTC} / 7.5 \mathrm{ml}$ of blood) to favorable ( $<5 \mathrm{CTC} / 7.5 \mathrm{ml}$ of blood) improves survival and could be used as a predictive factor of treatment response $[13,17]$. However, only a fraction of the tumor cells that are shed into the bloodstream are believed to succeed in establishing secondary tumors [40]. There are also indications that trapped tumor cells in the lungs are destroyed due to mechanical aspects such as frictional and shearing forces [41]. Still, an increase of trapped malignant cells to the lungs would likely increase the risk of metastasis [11].

The pathways of possible CTCs originating from primary breast cancers are largely undetermined. In order to reach the peripheral veins (from where blood was drawn in this study), CTCs need to pass both the capillaries of the lungs and the capillary beds of the extremities without being trapped. This process is poorly understood, as the size of a CTC is often in the order of 5-12 $\mu \mathrm{m}$ (and sometimes considerably larger) compared to the capillaries' internal diameters of around 3-7 $\mu \mathrm{m}$. In addition, carcinoma cells are not especially deformable compared to erythrocytes, making CTCs ill suited for passage [42]. Possible explanations of CTCs bypassing capillaries are that they become smaller by pinching off large amounts of cytoplasm or that they travel through arterio-venous shunts [43]. Thus, we cannot exclude the dissemination of tumor cells as a result of applied breast compression; however, the cells might not reach the peripheral blood due to filtration in the capillary beds. For example, grade 3 tumors in general have larger, polymorphous cells and should thus have a greater tendency to be trapped in the lung capillaries. Animal studies indicate that a majority of cancer cells injected intravenously are arrested in the microvasculature of the lungs [42, 44, 45] and that the passage through small capillaries is also tumor dependent [46]. Furthermore, the CTC count has been shown to be higher in the central veins compared to the peripheral veins [4749]. As an extension of the current study on the effect of breast compression, we intend to draw blood from the superior vena cava in breast cancer patients undergoing preoperative chemotherapy, in addition to peripheral vein sampling, in order to assess the sieving of CTCs in the lung capillaries.

In conclusion, this pilot study supports the view that mammography is a safe procedure from the point of view of malignant cell shedding to peripheral blood.

Acknowledgments The authors would like to thank G. Dinnetz, E. Edvik, and E. Undrén for logistics and blood sample collection, and S. Baker and C. Welinder for processing blood samples. We also thank Gunnar Nilssons Cancerstiftelse, Magnus Bergvalls Stiftelse, Region Skåne (regional forskningsstöd) and Stiftelsen för cancerforskning vid Onkologiska kliniken vid Universitetssjukhuset MAS, for financial support.

Conflict of interest The authors declare that they have no conflict of interest.

Open Access This article is distributed under the terms of the Creative Commons Attribution Noncommercial License which permits any noncommercial use, distribution, and reproduction in any medium, provided the original author(s) and the source are credited.

\section{References}

1. Watmough DJ, Quan KM (1992) X-ray mammography and breast compression. Lancet 340(8811):122

2. Watmough DJ, Quan KM, Aspden RM (1993) Breast compression: a preliminary study. J Biomed Eng 15(2):121-126

3. van Netten JP, Cann SA, Glover DW (1999) Mammographic compression: a force to be reckoned with. $\mathrm{Br} \mathrm{J}$ Cancer 81(8):1426-1427

4. Choy A, McCulloch P (1996) Induction of tumor cell shedding into effluent venous blood breast cancer surgery. $\mathrm{Br} \mathrm{J}$ Cancer 73(1):79-82

5. Hayashi N, Egami H, Kai M, Kurusu Y, Takano S, Ogawa M (1999) No-touch isolation technique reduces intraoperative shedding of tumor cells into the portal vein during resection of colorectal cancer. Surgery 125(4):369-374

6. Yamaguchi K, Takagi Y, Aoki S, Futamura M, Saji S (2000) Significant detection of circulating cancer cells in the blood by reverse transcriptase-polymerase chain reaction during colorectal cancer resection. Ann Surg 232(1):58-65

7. Weitz J, Koch M, Kienle P, Schrödel A, Willeke F, Benner A, Lehnert T, Herfarth C, von Knebel Doeberitz M (2000) Detection of hematogenic tumor cell dissemination in patients undergoing resection of liver metastases of colorectal cancer. Ann Surg 232(1):66-72

8. Uchikura K, Takao S, Nakajo A, Miyazono F, Nakashima S, Tokuda K, Matsumoto M, Shinchi H, Natsugoe S, Aikou T (2002) Intraoperative molecular detection of circulating tumor cells by reverse transcription-polymerase chain reaction in patients with biliary-pancreatic cancer is associated with hematogenous metastasis. Ann Surg Oncol 9(4):364-370

9. Tyzzer EE (1913) Factors in the production and growth of tumor metastases. J Med Res 28(2):309-332

10. Romsdahl MM, McGrath RG, Hoppe E, McGrew EA (1965) Experimental model for the study of tumor cells in the blood. Acta Cytol 9:141-145

11. Liotta LA, Kleinerman J, Saidel GM (1974) Quantitative relationships of intravascular tumor cells, tumor vessels, and pulmonary metastases following tumor implantation. Cancer Res 34(5):997-1004 
12. Nishizaki T, Matsumata T, Kanematsu T, Yasunaga C, Sugimachi K (1990) Surgical manipulation of VX2 carcinoma in the rabbit liver evokes enhancement of metastasis. J Surg Res 49(1):92-97

13. Cristofanilli M, Budd GT, Ellis MJ, Stopeck A, Matera J, Miller MC, Reuben JM, Doyle GV, Allard WJ, Terstappen LW, Hayes DF (2004) Circulating tumor cells, disease progression, and survival in metastatic breast cancer. N Engl J Med 351(8):781-791

14. de Bono JS, Scher HI, Montgomery RB, Parker C, Miller MC, Tissing H, Doyle GV, Terstappen LW, Pienta KJ, Raghavan D (2008) Circulating tumor cells predict survival benefit from treatment in metastatic castration-resistant prostate cancer. Clin Cancer Res 14(19):6302-6309. doi:10.1158/1078-0432.CCR-080872

15. Bidard FC, Mathiot C, Delaloge S, Brain E, Giachetti S, de Cremoux P, Marty M, Pierga JY (2010) Single circulating tumor cell detection and overall survival in nonmetastatic breast cancer. Ann Oncol 21(4):729-733. doi:10.1093/annonc/mdp391

16. Budd GT, Cristofanilli M, Ellis MJ, Stopeck A, Borden E, Miller MC, Matera J, Repollet M, Doyle GV, Terstappen LW, Hayes DF (2006) Circulating tumor cells versus imaging-predicting overall survival in metastatic breast cancer. Clin Cancer Res 12(21): 6403-6409

17. Hayes DF, Cristofanilli M, Budd GT, Ellis MJ, Stopeck A, Miller MC, Matera J, Allard WJ, Doyle GV, Terstappen LW (2006) Circulating tumor cells at each follow-up time point during therapy of metastatic breast cancer patients predict progressionfree and overall survival. Clin Cancer Res 12(14 Pt 1):4218-4224

18. Krishnamurthy S, Cristofanilli M, Singh B, Reuben J, Gao H, Cohen EN, Andreopoulou E, Hall CS, Lodhi A, Jackson S, Lucci A (2010) Detection of minimal residual disease in blood and bone marrow in early stage breast cancer. Cancer 116(14):3330-3337. doi: $10.1002 / \mathrm{cncr} .25145$

19. Stathopoulou A, Vlachonikolis I, Mavroudis D, Perraki M, Kouroussis Ch, Apostolaki S, Malamos N, Kakolyris S, Kotsakis A, Xenidis N, Reppa D, Georgoulias V (2002) Molecular detection of cytokeratin-19-positive cells in the peripheral blood of patients with operable breast cancer: evaluation of their prognostic significance. J Clin Oncol 20(16):3404-3412

20. Rack B, Schindlbeck C, Andergassen U, Lorenz R, Zwingers T, Schneeweiss A, Lichtenegger W, Beckmann MW, Sommer H, Pantel K, Friese K, Janni W (2010) Prognostic relevance of circulating tumor cells in the peripheral blood of primary breast cancer patients. In: 33rd Annual San Antonio Breast Cancer Symposium: 8-12 Dec 2010, San Antonio, USA. (abstr 503)

21. Lucci A, Hall CS, Lodhi AK, Bhattacharyya A, Anderson AE, Xiao L, Bedrosian I, Kuerer HM, Krishnamurthy S (2012) Circulating tumor cells in non-metastatic breast cancer: a prospective study. Lancet Oncol 13(7):688-695. doi:10.1016/S14702045(12)70209-7

22. Franken B, de Groot MR, Mastboom WJ, Vermes I, van der Palen J, Tibbe AG, Terstappen LW (2012) Circulating tumor cells, disease recurrence and survival in newly diagnosed breast cancer. Breast Cancer Res 14(5):R133

23. Dustler M, Andersson I, Brorson H, Fröjd P, Mattsson S, Tingberg A, Zackrisson S, Förnvik D (2012) Breast compression in mammography: pressure distribution patterns. Acta Radiol 53(9):973-980. doi:10.1258/ar.2012.120238

24. Luo ZP, Berglund LJ, An KN (1998) Validation of F-scan pressure sensor system: a technical note. J Rehabil Res Dev 35(2):186-191

25. Morin EL, Bryant JT, Reid SA, Whiteside RA (2001) Calibration issues of Tekscan systems for human pressure assessment. In: RTO meeting proceedings 56-soldier mobility: innovations in load carriage system design and evaluation, May 2001, Ottawa/ Hull, St Joseph, Canada, pp 251-257
26. Allard WJ, Matera J, Miller MC, Repollet M, Connelly MC, Rao C, Tibbe AG, Uhr JW, Terstappen LW (2004) Tumor cells circulate in the peripheral blood of all major carcinomas but not in healthy subjects or patients with nonmalignant diseases. Clin Cancer Res 10(20):6897-6904

27. Riethdorf S, Fritsche H, Müller V, Rau T, Schindlbeck C, Rack B, Janni W, Coith C, Beck K, Jänicke F, Jackson S, Gornet T, Cristofanilli M, Pantel K (2007) Detection of circulating tumor cells in peripheral blood of patients with metastatic breast cancer: a validation study of the CellSearch system. Clin Cancer Res 13(3):920-928

28. Tibbe AG, Miller MC, Terstappen LW (2007) Statistical considerations for enumeration of circulating tumor cells. Cytometry A 71(3):154-162

29. Pierga JY, Bidard FC, Mathiot C, Brain E, Delaloge S, Giachetti S, de Cremoux P, Salmon R, Vincent-Salomon A, Marty M (2008) Circulating tumor cell detection predicts early metastatic relapse after neoadjuvant chemotherapy in large operable and locally advanced breast cancer in a phase II randomized trial. Clin Cancer Res 14(21):7004-7010. doi:10.1158/1078-0432.CCR-08-0030

30. Wolff AC, Hammond ME, Schwartz JN, Hagerty KL, Allred DC, Cote RJ, Dowsett M, Fitzgibbons PL, Hanna WM, Langer A, McShane LM, Paik S, Pegram MD, Perez EA, Press MF, Rhodes A, Sturgeon C, Taube SE, Tubbs R, Vance GH, van de Vijver M, Wheeler TM, Hayes DF (2007) American Society of Clinical Oncology/College of American Pathologists guideline recommendations for human epidermal growth factor receptor 2 testing in breast cancer. J Clin Oncol 25(1):118-145

31. Biggers B, Knox S, Grant M, Kuhn J, Nemunatitis J, Fisher T, Lamont J (2009) Circulating tumor cells in patients undergoing surgery for primary breast cancer: preliminary results of a pilot study. Ann Surg Oncol 16(4):969-971. doi:10.1245/s10434-0090314-y

32. Riethdorf S, Müller V, Zhang L, Rau T, Loibl S, Komor M, Roller M, Huober J, Fehm T, Schrader I, Hilfrich J, Holms F, Tesch H, Eidtmann H, Untch M, von Minckwitz G, Pantel K (2010) Detection and HER2 expression of circulating tumor cells: prospective monitoring in breast cancer patients treated in the neoadjuvant GeparQuattro trial. Clin Cancer Res 16(9):2634-2645. doi:10.1158/1078-0432.CCR-09-2042

33. Pantel K, Denève E, Nocca D, Coffy A, Vendrell JP, Maudelonde T, Riethdorf S, Alix-Panabières C (2012) Circulating epithelial cells in patients with benign colon diseases. Clin Chem 58(5):936-940. doi:10.1373/clinchem.2011.175570

34. Kopans DB (1994) Physical trauma and breast cancer. Lancet 343(8909):1364-1365

35. Pennes DR, Homer MJ (1987) Disappearing breast masses caused by compression during mammography. Radiology 165(2):327-328

36. Raimondi C, Gradilone A, Naso G, Vincenzi B, Petracca A, Nicolazzo C, Palazzo A, Saltarelli R, Spremberg F, Cortesi E, Gazzaniga P (2011) Epithelial-mesenchymal transition and stemness features in circulating tumor cells from breast cancer patients. Breast Cancer Res Treat 130(2):449-455. doi:10.1007/ s10549-011-1373-x

37. Spizzo G, Went P, Dirnhofer S, Obrist P, Simon R, Spichtin H, Maurer R, Metzger U, von Castelberg B, Bart R, Stopatschinskaya S, Köchli OR, Haas P, Mross F, Zuber M, Dietrich H, Bischoff S, Mirlacher M, Sauter G, Gastl G (2004) High EpCAM expression is associated with poor prognosis in node-positive breast cancer. Breast Cancer Res Treat 86(3):207-213

38. Meng S, Tripathy D, Frenkel EP, Shete S, Naftalis EZ, Huth JF, Beitsch PD, Leitch M, Hoover S, Euhus D, Haley B, Morrison L, Fleming TP, Herlyn D, Terstappen LW, Fehm T, Tucker TF, Lane N, Wang J, Uhr JW (2004) Circulating tumor cells in patients with breast cancer dormancy. Clin Cancer Res 10(24):8152-8162 
39. Li Y, Guo J, Wang C, Fan Z, Liu G, Wang C, Gu Z, Damm D, Mosig A, Wei X (2011) Circulation times of prostate cancer and hepatocellular carcinoma cells by in vivo flow cytometry. Cytometry A 79(10):848-854. doi:10.1002/cyto.a.21134

40. Weiss L (1990) Metastatic inefficiency. Adv Cancer Res 54:159-211

41. Weiss L, Orr FW, Honn KV (1989) Interactions between cancer cells and the microvasculature: a rate-regulator for metastasis. Clin Exp Metastasis 7(2):127-167

42. Weiss L, Orr FW, Honn KV (1988) Interactions of cancer cells with the microvasculature during metastasis. FASEB J 2(1):12-21

43. Weinberg RA (2007) Moving out: invasion and metastasis. In: Weinberg RA (ed) The biology of cancer. Garland Science, Taylor \& Francis Group, New York, pp 587-654

44. Fidler IJ (1970) Metastasis: quantitative analysis of distribution and fate of tumor emboli labeled with 125 I-5-iodo-2'-deoxyuridine. J Natl Cancer Inst 45(4):773-782

45. Mizuno N, Kato Y, Shirota K, Izumi Y, Irimura T, Harashima H, Kiwada H, Motoji N, Shigematsu A, Sugiyama Y (1998)
Mechanism of initial distribution of blood-borne colon carcinoma cells in the liver. J Hepatol 28(5):878-885

46. Zeidman I (1961) The fate of circulating tumors cells. I. Passage of cells through capillaries. Cancer Res 21:38-39

47. Jiao LR, Apostolopoulos C, Jacob J, Szydlo R, Johnson N, Tsim N, Habib NA, Coombes RC, Stebbing J (2009) Unique localization of circulating tumor cells in patients with hepatic metastases. J Clin Oncol 27(36):6160-6165. doi:10.1200/JCO.2009.24.5837

48. Wind J, Tuynman JB, Tibbe AG, Swennenhuis JF, Richel DJ, van Berge Henegouwen MI, Bemelman WA (2009) Circulating tumor cells during laparoscopic and open surgery for primary colonic cancer in portal and peripheral blood. Eur J Surg Oncol 35(9):942-950. doi:10.1016/j.ejso.2008.12.003

49. Peeters DJ, Van den Eynden GG, van Dam PJ, Prové A, Benoy $\mathrm{IH}$, van Dam PA, Vermeulen PB, Pauwels P, Peeters M, Van Laere SJ, Dirix LY (2011) Circulating tumor cells in the central and the peripheral venous compartment in patients with metastatic breast cancer. Br J Cancer 104(9):1472-1477. doi:10.1038/ bjc. 2011.122 